\title{
University Student Engagement Scale: Develop- MENT AND VALIDATION IN INDIAN CONTEXT
}

\author{
Savita Gupta (iD and Renu NagpaliD
}

In academic achievement, student engagement is considered a prime factor to enhance motivation among students. Student engagement is a constructive approach that refers to the level of concentration, inquisitiveness, and enthusiasm that students demonstrate when they learn. The study aims to elucidate the development of a three-dimensional construct of student engagement based on psycho-education oriented measures such as behavioural, cognitive and emotional engagement. Data from 470 students studying in science, humanities, and engineering streams from different universities of Punjab, was collected via random sampling technique. The factor analysis of the scale reveals that 31 items had three factors, behavioural, cognitive, and affective engagement. Good internal reliability $(\alpha=0.889)$ and adequate convergent and discriminant validities are reported, which establishes good psychometric properties of the scale.

KEYWORDS: Student Engagement, University Students, Scale Development, Factor Analysis

\section{INTRODUCTION}

The term student engagement came into existence when the relationship between students' learning and the amount of time spent on course work was studied. According to Nystrand and Gamoran (1992) student engagement can be defined as the "students' willingness to participate in routine school activities, such as attending classes, submitting required work and following

\author{
Savita Gupta \\ Faculty of Education, Lovely Professional University, Jallandhar, India. \\ Email: savita.gupta@lpu.co.in. ORCID: ORCID: https://orcid.org/0000-0001-6458-0460 \\ Renu Nagpal $\square$ \\ Faculty of Education, Lovely Professional University, Jallandhar, India. \\ Email: nagpalrenu79@gmail.com. ORCID: ORCID: https://orcid.org/0000-0002-1195-0373
}

This is an open access article distributed under the terms of the Creative Commons Attribution License (CC BY 4.0), which permits unrestricted use, distribution, and reproduction in any medium, provided the original author and source are credited. 
teachers' instructions in class". Many studies have been carried out in recent years to find out the effect of quality and quantity of student's efforts on their learning and the contribution of individual dispositions leading to student engagement (Martin, Goldwasser \& Galentino, 2017; Gilboy, Heinerichs \& Pazzaglia, 2015; Bakker, Vergel \& Kuntze, 2015; Pellas, 2014). Many cultural, social, and psychological perspective-based definitions of student engagement were curated and inferred as a complex phenomenon (Wimpenny \& Savin-Baden, 2013; Leach \& Zepke, 2010; Fredricks et al. 1994).

Based on the literature, two sets of explanation of student engagement came into existence. One set revealed it as a required result of a pupil's behaviour, thoughts, and feelings for the learning process. It is an "individual psychological state" as revealed by Kahu (2013), comprised of student's behaviour, cognition, and affect. Their findings primarily consider student behaviour as a key factor for student engagement. Further, it was elaborated that student engagement need is correlated with high-quality learning outcomes (Coates, 2008). It has also been comprehended that the excellent efforts and participation in dynamic learning activities is called student engagement. Second set of definitions takes student engagement as a phenomenon which comprises "the interaction between the time, effort and other relevant resources invested by both students and their institutions intended to optimize the student experience, development of students' performance and enhance the reputation of the institution" (Trowler, 2010). Similarly, student engagement as per National Survey of Student Engagement (NSSE) website is "the amount of time and effort students put into their studies and other educationally purposeful activities" as well as "how the institution deploys its resources and organizes the curriculum and other learning opportunities to get students to participate in activities" (Center for Postsecondary Research, 2017). The student engagement process is based on three areas which include the influencing factors, indicators and outcomes of student engagement. Influencing factors of student engagement includes curriculum, teaching practices, and institutional culture. Whereas indicators mean interaction of students with classmates and teachers, interest in learning and dispensation of meaningful information, and outcomes include student's personal growth, academic achievement, and retention Kahu (2013) .

In a study by J. A. Fredricks, Blumenfeld, Friedel, and Paris (2004) the topology of student engagement has been used which revealed three types of student engagement; cognitive, affective, and behavioural. The topology includes various types of engagements encircling a wide range of student experiences. Above all, it focuses on student-centred indicators particularly, rather than taking faculty behaviour, campus environment, and curriculum design as a combination of student indicators (Coates, 2008; Kuh, 2009). Faculty behaviour, campus environment, and curriculum are important parts 
of student engagement. To get a better understanding of conceptualization of cognitive, emotional, and behavioural engagements, the particular indicators corresponding to each type of engagement must be considered. Behavioural engagement includes the extent of students involved in different learning activities (J. A. Fredricks et al., 2004; Kahu, 2013). Students' efforts and time spent in learning activities (Coates, 2008; J. A. Fredricks et al., 2004; Kahu, 2013; Kuh, 2009) and their interaction with staff, faculty, and peers (Coates, 2008; Kuh, 2009) are indicators of behavioural engagement. The original conceptualization of student engagement is based on the quality and quantity of efforts devoted for learning and can be seen clearly as the indicators of behavioural engagement (Pace, 1980 \& Astin, 1984). Affective engagement includes the emotional reaction of students to their learning process. Values, attitude, and interest towards learning, sense of belongingness with their learning community are indicators of affective engagements (J. A. Fredricks et al., 2004; Kahu, 2013).

To assess the affective engagement of student's self-report measures can be used. It helps in understanding the feeling of student about a delivery method of an instructor. Finally, students' mental effort which they invest in understanding and mastering the content during the learning process is cognitive engagement (J. A. Fredricks et al., 2004) . Persistence of students to meet academic requirements (Kuh, 2009), their motivation for learning and deep information processing through their active knowledge construction (Coates, 2008; Kuh, 2009), their critical thinking (Coates, 2008) and selfregulation (J. A. Fredricks et al., 2004) are the signs of cognitive engagement. However motivational aspect is included in cognitive engagement, major focus of the literature is on the use of students' higher order thinking and active learning for mastering the content. So, the importance of deep learning has been given significant emphasis. Deep learning includes analysis of new learning with their previous learning that is limited to rehearsal, recall, and memorization (J. A. Fredricks et al., 2004; Kahu, 2013). All three types of engagement have their distinct features, but overlapping can be seen across cognitive, affective, and behavioural domains. Overlapping can be observed among indicators where an indicator can be seen to correspond to more than one type of engagement. Consequently, alike indicators found in the literature are subsumed to avoid redundancy.

\section{Previous Measures of Student Engagement}

Literature has revealed that the studies on student engagement were majorly conducted in Australia and America on students of elementary, middle, and high schools. National Survey of Student Engagement (NSSE \& Indiana University Center for Postsecondary Research, 2012) and the Beginning 
College Survey of Student Engagement (BCSSE, 2013) were constructed to measure the engagement of students studying in the first year of US college Chambers and Chiang (2012) (Kuh, 2009; Mccormick \& Mcclenney, 2012). Some scholars criticized NSSE for its lack of good psychometric properties which include good construct and predictive validity and reliability (Campbell \& Cabrera, 2011; LaNasa, Cabrera, \& Trangsrud, 2009). Moreover, NSSE lacks measuring the psychological construct of student engagement directly rather it measured study habits of students, their college experience, and different aspects of their life (Wefald \& Downey, 2009). Many questions raised on NSSE were answered but some questions related to psychological construct and dimensionality of student engagement in various social and school contexts are still unanswered. There was another scale used in Australian Universities known as the seven 'calibrated' scales of first-year undergraduates' engagement which is again not very clear about the construct dimensionality. In contrast, it emphasised the importance of understanding engagement as a multidimensional construct (Coates, 2008) and these features, in the views of these scholars, are mandatory to be acknowledged in every measurement of higher education for this construct.

The Utrecht Work Engagement Scale- Student Survey (UWES-SS) which was developed in Europe to monitor the engagement of students in university settings namely UWES-SS (Schaufeli, Martinez, Pinto, Salanova, \& Bakker, 2002) was the adapted version of UWES which was made to measure work engagement at workplaces. So, the items which are exactly related to university are very few. The criticism cropped up from some of the scholars for its non- adaptation to the university settings and methodological limitations (Mills, Culbertson, \& Fullagar, 2012). The high school surveys which were developed for student engagement miss out some key points like attending seminars, and conferences which are essential for measuring engagement at the university level (J. Fredricks \& Mccolskey, 2012). Moreover, the dimensionality of construct varies with student's age. Maroco, Maroco, Campos, and Fredricks (2016) after reviewing the criticisms of approaches developed an inventory viz. the University Student Engagement Inventory (USEI) based on three dimensions behavioural, emotional, and cognitive of student engagement.

In many universities around the globe actions were taken to improve student's academic success and engagement, their wellbeing and academic achievement and reduce their burnout (Breso, Schaufeli, \& Salanova, 2011) (Chen \& Astor, 2011; Christenson \& Reschly, 2010; Elmore \& Huebner, 2010; J. A. Fredricks et al., 2004; Harlow, Debacker, \& Crowson, 2011; Kuh, 2009; Li \& Lerner, 2011). There was a dire need of increasing university students' engagement for their improved well-being and learning experiences and their success in higher education as a return to the academic investment (Christenson \& Reschly, 2010; 
Kuh, 2009). So, a good tool of university students' engagement with detailed psychometric properties and correlated with integration, course-work fulfilment, and academic achievement was required for education policymakers, school counsellors, and educational psychologists. Above all, a specific tool constructed for measuring student engagement in the Indian context has not been found. In this study, an attempt has been made for filling up the gap and producing a new set of items which can help measure student engagement at the university level in the Indian context. This study has drawn help from the work of J. A. Fredricks et al. (2004) and Schaufeli et al. (2002) on the Utrecht Work Engagement Scale- Student Survey (UWES-SS), to integrate Kahu's (2013) four perspectives in a single measurement tool for student engagement.

\section{Item Generation Procedure}

Statements of the University Student Engagement Scale were developed based on the theoretical framework. The items of the USE scale were generated to measure the engagement of university students. In the present scale, Likert's (1932) proposed procedure of summative assessment is used. 50 items for the university student engagement scale were identified from the existing instruments and aligned for getting responses. A 5-point Likert scale has been used to get responses. Five anchors, viz Always $=5$, Very Often $=4$, Sometimes $=3$, Rarely $=2$, and Never=1, have been used to rate each item of the USE scale. For producing an instrument with strong psychometric properties, guidance was taken from an extensive review of the literature, experts' reviews and the use of the Likert scale has provided much help to make the items stronger (DeVellis, 2016).

\section{Content Validity}

To establish content validity, critical discussion was carried out with six experts for developing a preliminary draft of the scale. The first draft of the scale consisted of 50 items. It was reviewed by six experts. The experts critically reviewed the content of each item and examined its relevancy and suitability for the scale. The statements which received $85 \%-90 \%$ agreement of the experts for their relevance to the scale under construction were retained for the second draft. In the views of the experts remaining 31 statements were relevant for measuring student engagement at the university level in the Indian context and were valid to carry out a pilot study. 


\section{RESPONDENTS}

For the pilot study of this scale, respondents were taken from different universities in Punjab, India. The study comprised 470 respondents from different universities, where 167 were male and 303 were females. A random sampling technique was used to select the universities in Punjab and respondents from the selected universities. The sample of this study covered undergraduate students of different streams such as engineering, arts, humanities, science, and management in the age range of 18-21 years. Total 500 questionnaires were circulated among students out of which 483 questionnaires with responses were received and these questionnaires were scrutinized for respondent detachment, comprehensiveness, values, and misplaced outliers (Hair et al., 2010). Incomplete questionnaires were discarded to get the final dataset for the study which was comprised of 470 respondents.

\section{EXPLORATORY FACTOR ANALYSIS}

Exploratory factor analysis (EFA) was the next step in the scale construction which was used to get information on the number of constructs requisite for the representation of the data. According to Child (1990) exploratory factor analysis discovers the probable original factor construction of a set of variables without imposing a predetermined structure on the consequence. Factors of the university student engagement scale were explored through EFA. Iterative cycles of factor analysis were employed on the dataset and after each iteration number of factors extracted and total variance were examined. The Maximum likelihood method for extraction and the Promax method for rotation was used to check the factors of 31 items. The Kaiser-Meyer-Olkin (KMO) was also calculated before exploratory factor analysis for measuring sampling acceptability. The calculated Kaiser-Meyer-Olkin (KMO) value was 0.958 and for a good factor structure, the minimum KMO should be 0.60 (Tabachnick \& Fidell, 1996). Bartlett's test of sphericity revealed a negligible significance level. Both the measures revealed adequacy of the sample data for performing factor analysis. Table 1 presents the detailed report of this.

A three-factor structure has been indicated by factor analysis. With $69.94 \%$ variance explained and loading of all items above 0.40. Heir et al., (2007) said that for a sample above 350 acceptable item loading is 0.40 .14 items are there in the first factor related to cognitive engagement, 9 items related to affective engagement are there in the second factor and in the third factor, 8 items related to behavioural engagement are there. Factor loadings of all the items of the three factors are given in Table 2. 
Table 1

KMO and Bartlett's Test Results.

\begin{tabular}{lll}
\hline \multicolumn{2}{l}{ Kaiser-Meyer-Olkin Measure of Sampling Adequacy } & 0.95 \\
\hline \multirow{3}{*}{ Bartlett's Test of Sphericity } & Chi-Square & 808.42 \\
& df & 375 \\
& Sig. & 0.00 \\
\hline
\end{tabular}

Table 2

Factor Loadings of Items.

\begin{tabular}{|c|c|c|}
\hline Items & Statements & $\begin{array}{l}\text { Factor } \\
\text { Loadings }\end{array}$ \\
\hline \multicolumn{3}{|c|}{ Dimension 1: Cognitive Engagement } \\
\hline CE10 & $\begin{array}{l}\text { I don't apply concepts learnt in the class to } \\
\text { solve day-to-day problems. }\end{array}$ & 0.89 \\
\hline CE5 & $\begin{array}{l}\text { I don't put intensive effort to complete my } \\
\text { assignments. }\end{array}$ & 0.89 \\
\hline CE18 & I am inquisitive to learn more concepts. & 0.88 \\
\hline CE7 & $\begin{array}{l}\text { I watch online programs on subjects that are } \\
\text { taught in the class. }\end{array}$ & 0.88 \\
\hline CE3 & I recheck my homework to correct mistakes. & 0.88 \\
\hline CE6 & $\begin{array}{l}\text { I consult people outside the university on the } \\
\text { topic that I study in the class. }\end{array}$ & 0.88 \\
\hline CE8 & $\begin{array}{l}\text { I engage myself in social networking sites to } \\
\text { update my knowledge. }\end{array}$ & 0.87 \\
\hline CE13 & I ask questions to clear my doubts. & 0.87 \\
\hline CE4 & $\begin{array}{l}\text { I study at home even when I do not have any } \\
\text { assignments. }\end{array}$ & 0.87 \\
\hline CE16 & I exhibit creativity in classroom projects. & 0.87 \\
\hline CE11 & $\begin{array}{l}\text { I immediately take action on the feedback } \\
\text { given by my teachers. }\end{array}$ & 0.87 \\
\hline CE15 & $\begin{array}{l}\text { I go to class without reading the material } \\
\text { recommended by teachers. }\end{array}$ & 0.86 \\
\hline CE1 & $\begin{array}{l}\text { If I do not understand any topic, I read it } \\
\text { again to comprehend it. }\end{array}$ & 0.86 \\
\hline CE9 & $\begin{array}{l}\text { I work on a project which needs a lot of } \\
\text { research. }\end{array}$ & 0.84 \\
\hline
\end{tabular}


Table 2 continued

\begin{tabular}{|c|c|c|}
\hline \multicolumn{3}{|c|}{ Dimension 2: Affective Engagement } \\
\hline AE1 & I feel associated with my university. & 0.84 \\
\hline AE7 & I am not friendly with my classmates. & 0.82 \\
\hline AE12 & My classmates are friendly with me. & 0.82 \\
\hline AE5 & $\begin{array}{l}\text { I follow the rules and regulations of the } \\
\text { university. }\end{array}$ & 0.81 \\
\hline AE10 & I don't feel associated with my teachers. & 0.81 \\
\hline AE8 & I enjoy working on tasks assigned to me. & 0.81 \\
\hline AE3 & $\begin{array}{l}\text { I don't feel any sense of achievement in my } \\
\text { university. }\end{array}$ & 0.81 \\
\hline AE11 & $\begin{array}{l}\text { I discuss with my classmates the possible } \\
\text { ways to improve my classwork. }\end{array}$ & 0.78 \\
\hline AE13 & $\begin{array}{l}\text { I help my classmates in solving their prob- } \\
\text { lems. }\end{array}$ & 0.57 \\
\hline \multicolumn{3}{|c|}{ Dimension 3: Behavioural Engagement } \\
\hline BE7 & I participate in physical fitness activities. & 0.83 \\
\hline BE9 & $\begin{array}{l}\text { I collaborate with teachers for different } \\
\text { activities. }\end{array}$ & 0.83 \\
\hline BE8 & I participate in various arts activities. & 0.81 \\
\hline BE1 & $\begin{array}{l}\text { I hone my professional skills in the Univer- } \\
\text { sity. }\end{array}$ & 0.81 \\
\hline BE11 & $\begin{array}{l}\text { I use social networking sites in my leisure } \\
\text { time. }\end{array}$ & 0.81 \\
\hline BE4 & I attend conferences/Seminars. & 0.79 \\
\hline BE5 & I participate in cultural events. & 0.78 \\
\hline BE13 & $\begin{array}{l}\text { I use social networking sites to communicate } \\
\text { with my teachers and fellow students. }\end{array}$ & 0.74 \\
\hline
\end{tabular}

\section{Confirmatory Factor AnAlysis}

A statistical technique that is used for confirmation of the structure of factors of an observed variables set is called confirmatory factor analysis. According to Sorbom, and Joreskog (2004) confirmatory factor analysis is the "linear structural relationship model". In the words of Suhr (2006), confirmatory factor analysis enables a researcher to test the existing relationship between observed variables and their underlying latent constructs. According to Gerbing and Hunter (1982), confirmatory factor analysis is a useful statistical method to get validity evidence which is applied to assess constructs with several items when statements of a scale have linear association with the scale average or total.

SPSS AMOS 22 version was used to apply CFA to the three factors 


\section{1 | Savita Gupta and Renu Nagpal}

which were extracted through EFA. The model indices are Goodness Fit Index $(\mathrm{GFI})=0.89$ (the value is acceptable if above 0.8 as suggested by Doll, Xia \& Torkzadeh, 1994; Baumgartner \& Homburg, 1995), AGFI=0.87, Root Mean Square of Approximation (RMSEA) $=0.04$, Chi-square $/ \mathrm{df}=2.12$ and Comparative Fit Index (CFI) $=0.96$. Figure 1 shows the final model of CFA with three factors and 31 items.

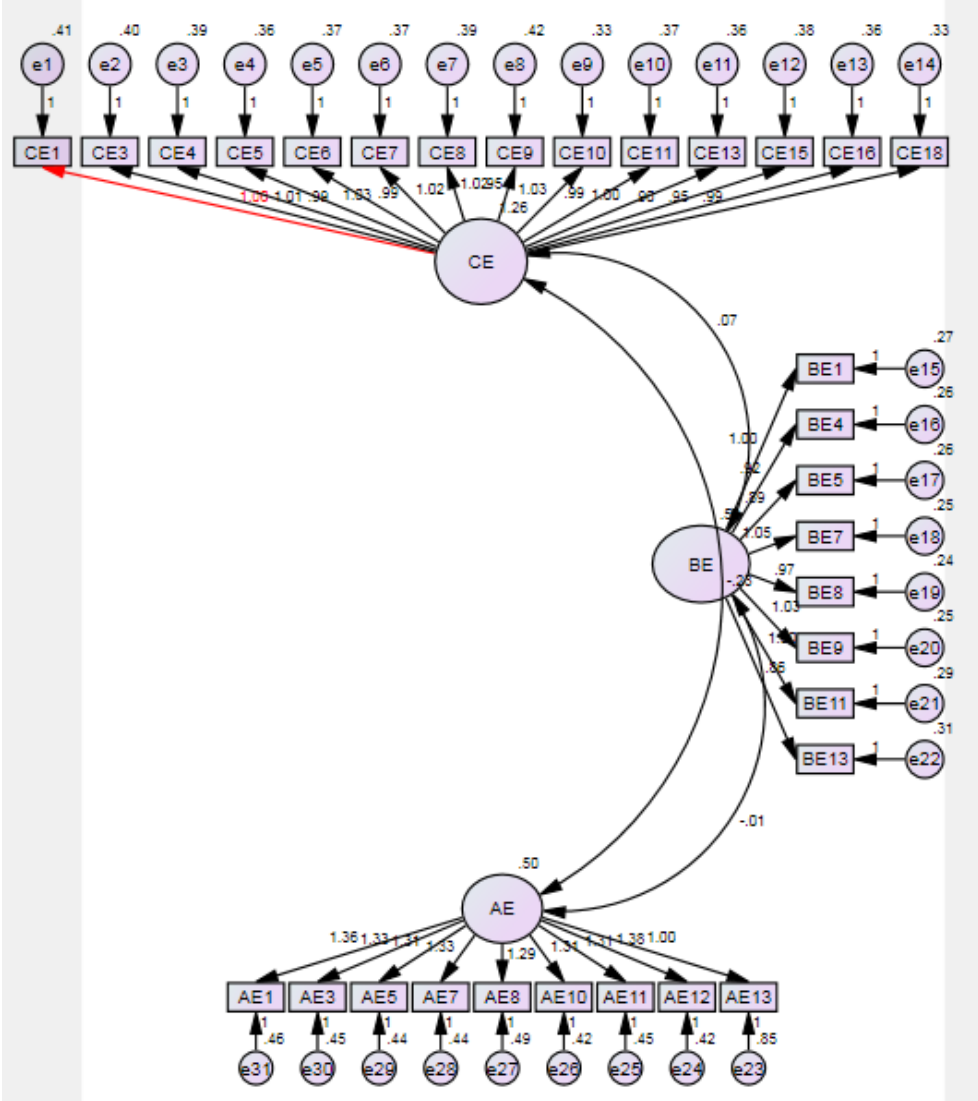

Figure 1. Confirmatory Factor Analysis.

\section{ReLiability ANALYsis}

For measuring the internal consistency of the items of a scale the Cronbach's alpha was calculated. The value of Alpha generally ranges from 0 to 1 (Gliem $\&$ Gilem, 2003). Cronbach's alpha value "above 0.80 is acceptable" (George 
\& Mallery, 2003). The calculated Cronbach's alpha for the university student engagement scale is $0.88(\alpha=0.88)$ which revealed good internal consistency of the scale items. Therefore, analysis of reliability conveys the good internal reliability of the university student engagement scale. Table 3 shows the reliability measure.

Table 3

Reliability Statistics.

\begin{tabular}{cc}
\hline Cronbach's Alpha & No. of Statements \\
\hline 0.88 & 31 \\
\hline
\end{tabular}

\section{Convergent VALidity}

For the present tool, convergent and discriminant validity of all the three factors was calculated as per the suggestions given by Fornell and Larcker (1981).

\section{Table 4}

Convergent Validity of University Student Engagement Scale.

\begin{tabular}{cc}
\hline Latent Variables & Average Variance Extracted (AVE) \\
\hline $\mathrm{AE}$ & 0.63 \\
$\mathrm{BE}$ & 0.64 \\
$\mathrm{CE}$ & 0.76 \\
\hline
\end{tabular}

Table 5

Discriminant Validity of University Student Engagement Scale.

\begin{tabular}{cccc}
\hline Latent Variables & AE & BE & CE \\
\hline AE & $\mathbf{0 . 7 9}$ & & \\
BE & -0.02 & $\mathbf{0 . 8 0}$ & \\
CE & -0.29 & 0.08 & $\mathbf{0 . 8 7}$ \\
\hline
\end{tabular}

The Average variance extract (AVE) calculated for the three factors ranged from 0.63 to 0.76 (shown in Table 4) which indicates convergent validity as AVE is more than 0.50 . The correlation of two factors smaller than the square root of AVE of the factors indicates discriminant validity (Fornell \& Larcker, 
1981; Maroco, 2014) which is mentioned in Table 5. The Convergent validity and discriminant validity of the three factors is shown in Table 4 and Table 5 respectively.

\section{CONCLUSION AND Discussion}

Effective learning is one of the most important goals of education and this can be achieved only if we know the level of students' engagement. The scale developed in the present study can help to improve the measurement of student engagement of university students in the Indian context. In the hectic and dynamic environment of today, student engagement plays a predictive role in student's academic achievement, well-being, satisfaction with an institution, dropout rate and lower burnout and this has already been shown in research (Chen \& Astor, 2011; Finn \& Zimmer, 2006; Kuh, 2009; Salmela-Aro \& Upadaya, 2012). A detailed review of literature of related studies measuring student engagement in a wide educational context has been drawn for this study. A meticulous methodological procedure has been carried out for developing and validating quantitatively a method for measuring student engagement of Indian university students. This scale has ample of theoretical and statistical support. Similar references of the extracted and validated factors of this scale can be seen in empirical studies. The factors cognitive engagement, behavioural engagement, and affective engagement have already been used by Lam and Jimerson (2008) in their Student Engagement in Schools Questionnaire (SESQ) and Maroco et al. (2016) for their university student engagement inventory. So, all these shreds of evidence show strong psychometric properties of this scale to measure student engagement of university students in the Indian context.

Based on theoretical findings the student engagement has been presented as a multidimensional construct in this study. USE scale shows a structure based on three factors, which indicates a higher-order student engagement construct. Student engagement conception in this study, as results have highlighted, can work well in different areas of university programs. However, stream specific tools are available (Wigfield et al., 2008; Kong et al., 2003), USE scale is a general tool of student engagement at the university level particularly and can measure the cognitive, affective, and behavioural engagement of students which cannot be observed directly (J. Fredricks \& Mccolskey, 2012).

\section{REFERENCES}

BCSSE. (2013). Beginning college survey of student engagement. Retrieved from https://bcsse.indiana.edu/_/?cid=15 
Breso, E., Schaufeli, W. B., \& Salanova, M. (2011). Can a self-efficacy-based intervention decrease burnout, increase engagement, and enhance performance? A quasi-experimental study. Higher Education, 61, 339-355. https://doi.org/10.1007/s10734-010-9334-6

Campbell, C. M., \& Cabrera, A. F. (2011). How sound is NSSE? Investigating the psychometric properties of NSSE at a public, research-extensive institution. The Review of Higher Education, 35(1), 77-103.

Chambers, T., \& Chiang, C. H. (2012). Understanding undergraduate students' experience: a content analysis using NSSE open-ended comments as an example. Quality \& Quantity, 46(4), 1113-1123.

Chen, J. K., \& Astor, R. A. (2011). School engagement, risky peers, and student-teacher relationships as mediators of school violence in Taiwanese vocational versus academically oriented high schools. Journal of Community Psychology, 39(1), 10-30.

Christenson, S. L., \& Reschly, A. L. (2010). Check \& connect: Enhancing school completion through student engagement. In B. Doll, W. Pfohl, \& J. Yoon (Eds.), Handbook of youth prevention science (p. 327-334). Routledge.

Coates, H. (2008). Attracting, engaging and retaining: New conversations about learning. Retrieved from http://research.acer.edu.au/cgi/ viewcontent.cgi? article $=1015 \&$ context $=$ auss

Elmore, G. M., \& Huebner, E. S. (2010). Adolescents' satisfaction with school experiences: Relationships with demographics, attachment relationships, and school engagement behavior. Psychology in the Schools, 47(6), 525-537.

Finn, J. D., \& Zimmer, K. S. (2006). Student engagement: What is it? Why does it matter? . In G. R. Hancock \& R. O. Mueller (Eds.), Structural equation modeling: a second course (p. 269-314). Greenwich, IAP.

Fornell, C., \& Larcker, D. F. (1981). Evaluating SEM with unobserved variables and measurement error. Journal of Market Research, 18, 3950.

Fredricks, J., \& Mccolskey, W. (2012). The measurement of student engagement: a comparative analysis of various methods and student self-report instruments. In S. L. Christenson, A. L. Reschly, \& C. Wylie (Eds.), Handbook of research on student engagement (p. 763-782). Springer.

Fredricks, J. A., Blumenfeld, P., Friedel, J., \& Paris, A. (2004). What do children need to flourish: conceptualizing and measuring indicators of positive development. In K. A. Moore \& L. H. Lippman (Eds.), School engagement (p. 305-321). Springer Science + Business Media.

Harlow, L., Debacker, T., \& Crowson, H. M. (2011). Need for closure, achievement goals, and cognitive engagement in high school 
students. The Journal of Educational Research, 104(2), 110-119.

Kahu, E. R. (2013). Framing student engagement in higher education. Studies in higher education, 38(5), 758-773. Retrieved from https://doi.org/10.1080/03075079.2011.598505 https:/ / doi.org/10.1080/03075079.2011.598505

Kuh, G. D. (2009). What student affairs professionals need to know about student engagement. Journal of college student development, 50(6), 683706.

LaNasa, S. M., Cabrera, A. F., \& Trangsrud, H. (2009). The construct validity of student engagement: A confirmatory factor analysis approach. Research in Higher Education, 50(4), 315-332.

Li, Y., \& Lerner, R. M. (2011). Trajectories of school engagement during adolescence: implications for grades, depression, delinquency, and substance use. Developmental psychology, 47(1), 233-233.

Maroco, J. (2014). Structural Equations Analysis: Theoretical foundations, software and software (2nd ed).

Maroco, J., Maroco, A. L., Campos, J. A. D. B., \& Fredricks, J. A. (2016). University student's engagement: development of the University Student Engagement Inventory (USEI). Psicologia: Reflexão e Crítica, 29.

Mccormick, A. C., \& Mcclenney, K. (2012). Will these trees ever bear fruit? A response to the special issue on student engagement. The Review of Higher Education, 35(2), 307-333.

Mills, M. J., Culbertson, S. S., \& Fullagar, C. J. (2012). Conceptualizing and measuring engagement: An analysis of the Utrecht Work Engagement Scale. Journal of Happiness Studies, 13(3), 519-545.

NSSE, \& Indiana University Center for Postsecondary Research. (2012). National survey of student engagement: promoting student learning and institutional improvement: lessons from NSSE at 13.

Nystrand, M., \& Gamoran, A. (1992). Instructional discourse and student engagement. In D. H. Schunk \& J. Meece (Eds.), Student perceptions in the classroom (p. 149-79). Lawrence Erlbaum.

Salmela-Aro, K., \& Upadaya, K. (2012). The schoolwork engagement inventory. European journal of psychological assessment.

Schaufeli, W. B., Martinez, I. M., Pinto, A. M., Salanova, M., \& Bakker, A. B. (2002). Burnout and engagement in university students: A cross-national study. Journal of cross-cultural psychology, 33(5), 464481. https://doi.org/10.1177/0022022102033005003

Wefald, A. J., \& Downey, R. G. (2009). Construct dimensionality of engagement and its relation with satisfaction. The Journal of Psychology, 143(1), 91-112. 